\title{
The Influence of Microfinance Institutions as Catalyst for Improved Performance of Small Scale Enterprises in Nigeria
}

\author{
Dr. Taofeek Aremu Kasali ${ }^{1}$ and Dr. FASHANU, Felix Adeniyi ${ }^{2}$ \\ ${ }^{1}$ School of Business and Management Studies, Moshood Abiola Polytechnic,Abeokuta, Ogun State Nigeria, \\ taofeekkasali2012@gmail.com \\ ${ }^{2}$ Department of Economics, McPherson University,Abeokuta, Ogun State Nigeria. \\ embeesfashydad@gmail.com
}

\begin{abstract}
The concept of microfinance through the Microfinance Institutions (MFIs) is to assist the Small and Medium Scale enterprises (SMEs) to increase productivity, create jobs and help eradicate poverty. This study was established to examine the impact of microfinance loans on the performance of SMEs. To achieve this objective, both descriptive and quantitative research design methods were adopted for the study. The data gathered were analyzed to provide insight into the impact of credit management practices on organizational performance and profitability. The result shows that MFIs can serve as bedrock for the growth of SMEs, economic development and grass root transformation. It is recommended that government should properly overhaul microfinance programmes in order to achieve the objective of poverty reduction through the disbursement of credit to SMEs. Also, there is need for more strategies and proactive measures to make MFIs and SMEs the agents of economic development in Nigeria. In addition, more awareness should be created for microfinance programmes by the operators to attract SMEs and the poor and downtrodden.
\end{abstract}

Keywords: Microfinance, economic development, small and medium scale enterprises, poverty eradication, Nigeria

\section{Introduction}

Microfinance Institutions (MFIs) in Nigeria are classified as private companies registered to embark on the business of offering microfinance services like savings, loans, insurance, money transfer services and other financial services that are needed by the economically poor, microsmall and medium enterprises (CBN, 2005). In essence, the MFIs do not attract financial aid 
or other assistance from the government. The Central Bank of Nigeria is only responsible for regulatory and supervision functions through its agencies.

According to the Central Bank of Nigeria (CBN, 2005), Microfinance Banks are established to serve the following objectives:

i. To create employment opportunities and increase the productivity of the active poor in the country, thereby increasing their individual household income and uplifting their standard of living.

ii. To enhance organized, systematic and focused participation of the poor in the socioeconomic development and resource allocation process.

iii. To mobilize savings in order to provide diversified, affordable and dependable financial sources to the poor, in a timely and competitive manner, that would enable them to undertake and develop long term sustainable entrepreneurial activities.

iv. To render payment services such as salaries, gratuities and pension for various tiers of government.

v. To give access to sustainable financial services that will increase the income and assets of the poor.

vi. To assist the small businesses against the vulnerability of external shocks.

vii. To help the households with adequate financial services that can raise enough funds for increase and sustainable income.

In Nigeria, it is on record that as at 2005, the formal financial system renders services to about $35 \%$ of the economically active population whereas the remaining $65 \%$ is left to the hands of informal financial sector like Non-Governmental Organisations (NGOs), money lenders, friends, relatives and Cooperative and Thrift societies. It is therefore important for developing country like Nigeria to enact a formidable finance policy that would integrate the activities of the existing informal financial institutions. And bring them within the umbrella of the apex regulator-Central Bank of Nigeria. This would ensure monetary stability that will be capable to engender sound economic growth and development through the adequate finance of micro, small and medium scale enterprises.

The practice of these microfinance services, in particular, those sponsored by government has been the adoption of the traditional supply-led, subsidized credit approach mainly directed to the agricultural sector and other businesses such as, tailoring, transportation, trading, blacksmithing, weaving and agro-processing. These programmes had contributed immensely to the economic growth but they lacked continuity and sustainability.

Some Non-Governmental Organisations (NGOs) also participate in microfinance activities. This was prompted by the lack of adequate funds from the formal financial sector to provide the services needed by the low income earners and the poor; and also with the declining support from development partners among others. Prominent among these NGOs are: Lift Above Poverty Organization (LAPO), Youth Empowerment Scheme (YES) in Minna, Country Women's Association of Nigeria (COWAN), The African Diaspora Foundation, Farmers' Development Association, Grassroots Women Foundation, People to People International and Women's Consortium of Nigeria. The NGOs are only membership based institutions that engage in charity, capital lending and credit. They shifted from supply-led technique to a demand driven strategy. Moreover, they could not reach out as expected because of the nonsustainability of the sources of their fund. 
From the private sector, about eight hundred and seventy Microfinance Institutions (MFIs) are owned by the private organizations all over the country. While appraising these institutions' activities in its December 2005 report, the Central Bank of Nigeria (apex regulator of Banks) affirms that:

The banks have weak institutional capacity. They are bedeviled by inadequate competent management, poor corporate governance and their operations are not well defined.

i. They have inadequate Capital Base. It is reported that only "75 out of over 600 community banks " whose financial statements of accounts were approved by the Central Bank of Nigeria in 2005 had up to N20million shareholders' funds unimpaired by losses.

ii. There has been a huge supply gap of unsatisfied demand in the market. As most of the poor people do not have access to financial services, particularly, the rural dwellers.

In summary, most of the microfinance banks have weak institutional capacity, inadequate capital base, they are not accessible to the poor and there has been a huge supply gap of unsatisfied demand in the market (CBN, 2005).

In its report at the $3^{\text {rd }}$ Annual General Meeting held in June, 2013, the National Association of Microfinance Banks (NAMB) in Nigeria claimed that its members had invested more than N222 billion into Nigeria's economy and provided jobs for 22,000 people from its activities nationwide with the total client of six million. The report further solicits assistance for more funds so that microfinance would be more accessible and effective with expected responsibilities in the Nigerian economy (NAN, 2013).

The Nigeria Deposit Insurance Corporation (NDIC), the government agency saddled with the responsibility of insuring deposit liabilities of licensed banks and other deposit taking institutions, also claimed that there exists a lot of untapped potential for financial services at the micro level of the Nigeria economy particularly in the rural areas where 76.8 percent of the residents are unbanked (Onukwugha, 2013).

Microfinance Institutions and programs have been recognized as agency of development strategy by serving as important tool for poverty reduction and upliftment of micro and small enterprises. It is expedient to assess the impact of microfinance programmes as literature is full of controversy as to the benefits derivable from such programmes.

Microfinance has emerged as a financial intermediation for the poor due to the failure of commercial and merchant banks to assist the low income people. The concept that microfinance assists the poor people; alleviate poverty by contributing to the microenterprises investment and increase the income of the poor, has led to the establishment of a global debate known as "microfinance revolution" ( Imai \& Azam, 2010).

There is no generally accepted definition of SMEs but it varies from country to country; according to economies and structure of the corporate sector. And mostly based on the thresholds of assets, staff employment and sales.

In Nigeria, the National Council of Industries defined SMEs as business enterprises whose total cost excluding land is not more than two million naira (N2, 000,000) only. However, the Federal Ministry of Commerce and Industry defines SMEs as firms with a total investment 
(excluding cost of land but including capital) of up to N750, 000, and paid employment of up to fifty (50) persons. (https://connectnigeria.com/articles/2015/08) .

The role of Small and Medium Scale Enterprises (SMEs) as the "live wire" of a developing economy like that of Nigeria cannot be over emphasised. Apart from the fact that they make substantial contributions to the Gross Domestic Product (GDP), they play dominant role in employment generation, serve as a reliable revenue source for the Government and encourage enhancement of inventions, adaptations and general technological development. They require low level of capital in their establishment and have a tendency to become feeders of large scale industries. The impending role of SMEs as catalyst for economic development notwithstanding, the sector is still bedeviled by challenges and impediments. One of such predicaments is that it has inadequate funding from financial institutions and government. This has limited the growth and development of Nigeria economy.

However, the importance of financing these business organisations cannot be overemphasized. This is due to the fact that finance serves as the pivot upon which other activities like production and marketing revolve. Almost all kinds of business activities directly or indirectly involve the acquisition and use of money. All facets of the production, marketing, personnel and other departments in an organisation rely on finance for carrying out their functions. Therefore, there is no gain saying the fact that appropriate and effective financial decisions will enhance growth, profitability and value of the business organisation.

Moreover, it has been asserted that for over three decades, MFIs have made frantic efforts to make capital available for poor households and SMEs but according to USAID (2005), SMEs have remained underserved and lacked adequate access to the loans and services of MFIs that would enhance productivity and expansion.

Taking cognizance of the importance of micro-finance and the role of SMEs in a developing country like Nigeria: and as a result of the problems stated above this study focused on the Impact of Micro-financing on the performance of small and medium scale enterprises (SMEs). The study is presented in five sections. Following the general introduction in section one is the review of relevant literature on the subject matter in section 2. Section three gives the materials and methods used in conducting the research. The outcome of the study is discussed in section four: while section five is on the conclusion and recommendation.

\section{Review of Literature}

Microfinance is an economic development strategy that aims at poverty reduction by providing financial services to the poor, low income earners, households and micro-entrepreneurs that are deprived of getting the same services from the formal financial market. These services include savings, credit, insurance and other development services like health, education, human empowerment, skill acquisition, training and environmental protection. Although microfinance is not a magic that can turn the poor into non-poor overnight, its development strategies and programmes can serve as a spring board that can uplift the poor households above the poverty line (Martin, Hulme \& Rutherford, 2002).

Microfinance can also be described as the process of advancing small loans to the poor with the aim of financing cottage and small scale businesses that would provide adequate income to take care of the recipients' responsibilities. Microfinance programmes which were originally designed to assist the poor households and advance credits to entrepreneurs also provide 
services like savings, rural credit, Agricultural credit, consumer credit and other financial services (Osei, 2002). In addition, their services include payment and insurance services to the poor people (Copestake, Duvendack, Hooper, Loke, Palmer-Jones, \& Rao, 2010). Microfinance also connotes the procedure of making available very small range of financial services to the poor with the purpose of making them take up new opportunities and participate in productive activities. It is a development tool that makes possible the rendering of services like money transfers, savings opportunities, and credit and insurance services. Microfinance entails both financial and social intermediation. Microfinance programmes can contribute to high standard of living if properly managed (Bashir et al., 2010; Muller \& Bibi, 2010). It is therefore an economic phenomenon that enhances the potentials of low income group.

Microcredit is a subset of microfinance. It finances microenterprises and poorest people that cannot afford to pledge collateral security to obtain loan from conventional banks. Therefore microcredit assists the poor to increase their living standard and their family welfare through short term credit facility that can generate revenue activity.

Studies have revealed that countries with well-organized and efficient financial intermediaries recover faster from poverty and inequality than their counterpart with moribund financial development and uncoordinated microfinance services (Kalirajan \& Singh, 2009; Yang, Jialali, \& Wei, 2011).

The operation of Microfinance can only thrive if the repayment schedule is met promptly by the customers. Empirical studies have shown that loan repayment is determined by the quality of the beneficiaries and other factors like education, distance of the lender to the customer's business, amount of loan, duration of the loan, gender and sanction threat to the borrowers (Roslan \& Abd Karim, 2009; N. Smith, 2010; Tang, 2002). It was also asserted that loan repayment would be more effective when the Microfinance Institutions relax their stringent conditions and give the programmes adequate supervision with realistic loan repayment procedure. This can also encourage adequate participation of the poor (Ali, A.H., Abu-Hadi, \& Ali, 2013). In another development, factors like loan size, outreach, shocks, officer's experience and training duration were considered as the major determinants of microfinance loan repayment (Onyeagocha, Chidebelu, Okorji, Ukoha, , Osuji, \& Korie, 2012).

The importance of microfinance in the development of small scale enterprises cannot be over emphasised. Green et.al. (2006) opine that the development of viral and efficient financial instrument like microfinance to fund micro and small enterprises will generate more employment; improve the standard of living, health, education, savings and serve as a formidable measure to reduce poverty. Also, Asghar (2012) affirms that Microfinance can serve as a strong tool to increase the income of the poor and household education. He concludes that income generated from the credit of microfinance will reduce poverty and increase both economic and social well beings.

In a study on the effect of micro-finance loans on SMEs in Nigeria, Ashamu (2014) opined that MFIs loans improved the activities of SMEs but cautioned that MFIs should embark on critical screening of SMEs to avoid defaults and bad debts. In a related development, Akpan and Nneji (2015) conducted a research on the contribution of MFIs to the development of small and medium scale enterprises in Nigeria. Data collected from 80 MFIs and 100 SMEs operators were analysed. The results revealed that MFIs contribute positively to the performance and growth of SMEs in Nigeria. Yeboah (2017) studied the impact of Microfinance on grassroots 
development in Kwabre East District of Ashanti Region in Ghana. Structured questionnaires were administered to 82 respondents. The results revealed that microfinance had some impacts on grassroots development.

From the literature review above it is evident that MFIs have made some favourable contributions towards the growth of SMEs in particular and economic development in general; the impediments earlier enunciated in the introduction passage of this study notwithstanding. However, there are still substantial issues that are yet to be addressed for the SMEs' Sub-sector in Nigeria in order to make it catalyst for the economic development. This is the vacuum that this study intends to fill in the literature.

\section{Methodology}

In this study data were collected through self-administered questionnaires distributed personally to the respondents. A descriptive survey was selected because it provides an accurate portrayal or account of the characteristics. This design was employed to meet the objectives of the study, which is to determine the effect of MFIs on the performance of Small and Medium Scale Enterprises. The population of this study is 175 comprising 80 Staff of a popular Microfinance Bank in Nigeria and 95 active customers who operate Small Business firms and are beneficiaries of the MFI loans. Out of the lot, the sample size adopted from the population was sixty-four (64) respondents. This was selected with the use of stratified sampling technique in which the strata include staff of firm as well as its respective customers. A total of 64 questionnaires were administered in order to ascertain the perceptions of both staff and customers with respect to the effect of MFI.

Ordinal scale was employed to measure the relationship between variables in the study. The Ordinal Scale is a rank order scale in which the numbers are assigned to the objects to determine the relative extent to which certain characteristic is possessed. It helps in identifying whether the object has more or less of a characteristic as compared to another object, but does not state about how much or less the characteristic is. Except for the demographic factors, all the other variables included in this study were measured using multiple items drawn from previous researches.

The method adopted in presentation of the data is simple percentage method of tabular presentation. The correlation test analysis was employed to test the stated hypothesis and to test the significant relationship between the actual and the observed variables; this was done via the aid of Statistical Package for Social Science (SPSS). In analyzing the data, frequency and descriptive tables were used as analytical tools. Qualitative explanations were made of quantitative data to give meaning to them as well as explain their implications. From these, appropriate conclusions and recommendations were made from the findings of the research.

\section{Results and Discussion}

The strength of reliability and validity of the questionnaire is as shown below using the Cronbach's alpha reliability test statistics. The decision is to conclude that the questions are reliable if the Cronbach's is close to 1.00

Table1: Reliability Statistics 


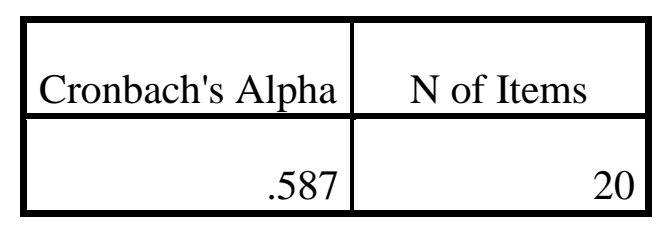

Source: Authors' Field Survey (2019).

From table 1, it is evident that the Cronbach's alpha (0.587) is close to 1.00 , we therefore conclude that the questions and items of the questionnaire are strongly reliable and valid.

A total of Sixty-four (64) questionnaires were distributed among respondents and out of which Sixty (60) were returned. This is illustrated in table 2.

Table 2 Rate of Response by Respondents

\begin{tabular}{|l|l|l|}
\hline Questionnaire & Respondents & Percentage (\%) \\
\hline Returned & 60 & $96 \%$ \\
\hline Not Returned & 4 & $4 \%$ \\
\hline Total & 64 & $100 \%$ \\
\hline
\end{tabular}

Source: Source: Authors' Field Survey (2019).

The above illustrated returned questionnaires are analyzed as follows:

Analysis of Demographic Characteristics of Respondents

Table 3: Distribution of Respondents by Sex

\begin{tabular}{|rr|r|r|r|r|}
\hline & Frequency & Percent & Valid Percent & $\begin{array}{c}\text { Cumulative } \\
\text { Percent }\end{array}$ \\
\hline & Male & 42 & 70.0 & 70.0 & 70.0 \\
Valid $\quad$ Female & 18 & 30.0 & 30.0 & 100.0 \\
& Total & 60 & 100.0 & 100.0 & \\
\hline
\end{tabular}

Source: Authors' Field Survey (2019). 
Table 3 illustrates that $70 \%$ of the respondents are male and $30 \%$ of the remaining respondents are female. This implies that majority of the respondents are male. By implications, this analysis revealed that there are more industrious personnel to the firm.

Table 4: Distribution of Respondents by Age

\begin{tabular}{|c|c|c|c|c|c|}
\hline & & Frequency & Percent & Valid Percent & $\begin{array}{c}\text { Cumulative } \\
\text { Percent }\end{array}$ \\
\hline \multirow{6}{*}{ Valid } & Below 25 years & 12 & 20.0 & 20.0 & 20.0 \\
\hline & 26-30 years & 14 & 23.3 & 23.3 & 43.3 \\
\hline & 30-39 years & 16 & 26.7 & 26.7 & 70.0 \\
\hline & $40-49$ years & 10 & 16.7 & 16.7 & 86.7 \\
\hline & 50 years and above & 8 & 13.3 & 13.3 & 100.0 \\
\hline & Total & 60 & 100.0 & 100.0 & \\
\hline
\end{tabular}

\section{Source: Authors' Field Survey (2019).}

Table 4 indicates that $20 \%$ of the respondents are within the age bracket of below 25 years, $23.3 \%$ of the respondents are within the age bracket of $26-30$ years, $26.7 \%$ of the respondents are within the age bracket of 30-39 years and $16.7 \%$ of the respondents are within 40-49 years and $13.3 \%$ of the respondents are 50 years and above. This implies that majority of the respondents are within the age limit of 30-39 years. By implication, this result shows that both the staff and customers of the bank are matured enough to give opinions on the subject matter.

Table 5: Distribution of Respondents by Marital status

\begin{tabular}{|rl|r|r|r|r|}
\hline & Frequency & Percent & Valid Percent & \multicolumn{2}{c|}{$\begin{array}{c}\text { Cumulative } \\
\text { Percent }\end{array}$} \\
\hline \multirow{4}{*}{ Valid } & Single & 14 & 23.3 & 23.3 & 23.3 \\
& Married & 43 & 71.7 & 71.7 & 95.0 \\
& Divorced & 3 & 5.0 & 5.0 & 100.0 \\
& Total & 60 & 100.0 & 100.0 & \\
\hline
\end{tabular}

\section{Source: Authors' Field Survey (2019).}

Table 5 indicates that $23.3 \%$ of the respondents are single, $71.7 \%$ of the respondents are married and $5 \%$ of the respondents are divorced. This implies that most of the respondents are married. By implication, the respondents are capable to give reliable and vital information on the scope of the study. 
Table 6: Distribution of Respondents by Educational Qualification

\begin{tabular}{|c|c|c|c|c|c|}
\hline & & Frequency & Percent & Valid Percent & $\begin{array}{c}\text { Cumulative } \\
\text { Percent }\end{array}$ \\
\hline \multirow{4}{*}{ Valid } & BSc/HND & 43 & 71.7 & 71.7 & 71.7 \\
\hline & MSC/MBA & 7 & 11.7 & 11.7 & 83.3 \\
\hline & PHD & 10 & 16.7 & 16.7 & 100.0 \\
\hline & Total & 60 & 100.0 & 100.0 & \\
\hline
\end{tabular}

\section{Source: Authors' Field Survey (2019).}

Table 6 indicates that $71.7 \%$ of the respondents have BSc/HND as educational qualification, $11.7 \%$ of the respondents possessed MSC/MBA as educational qualification, $16.7 \%$ of the respondents has $\mathrm{PhD}$ as educational qualification. This implies that most of the respondents have BSC/HND as educational qualification. Since no O levels respondents are found, the implication of this analysis shows that, most of the respondents are knowledgeable and expose enough to give vital information on the study scope.

Table 7: Distribution of Respondents by Length of Experience in the organization

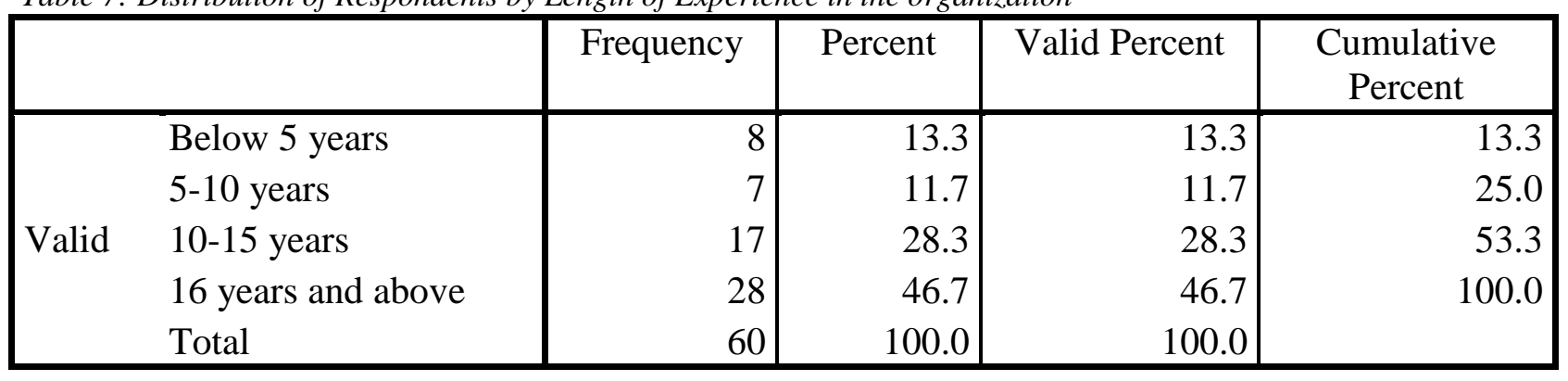

\section{Source: Authors' Field Survey (2019).}

Table 7 indicates that $13.3 \%$ of the respondents have working experience of below 5 years, $11.7 \%$ of the respondents have experience of within 5-10 years, $28.3 \%$ of the respondents have 10-15 years of experience and $46.7 \%$ of the respondents have 16 years and above working experience. This indicates that majority of the respondents have experience of 16 years and above in the business. With the indication of the above result, this implies that both customers and staff of the bank are experienced to give opinions on bank lending and SMEs performances.

\section{Test of hypotheses}

The Pearson correlation (r) was employed to test the association between the variables stated in the hypotheses at 0.01 level of significant. 
Decision Rule: Accept the Alternative Hypotheses and reject the Null Hypotheses if the Pearson correlation ( $r$ ) is positive. The level of strength between this variable can also be determined as indicated in a table 8:

\begin{tabular}{|l|l|}
\hline \multicolumn{1}{|c|}{ Coefficient Value } & \multicolumn{1}{c|}{ Strength of Association } \\
\hline $1.1</ \mathrm{r} /<.3$ & Small correlation \\
\hline $0.3</ \mathrm{r} /<.5$ & Medium/moderate correlation \\
\hline$/ \mathrm{r} />.5$ & Large/strong correlation \\
\hline
\end{tabular}

Where $\mathrm{r}$ means the absolute value of the Pearson correlation coefficient.

\section{Hypothesis one}

$\mathbf{H}_{1}$ : There is a correlation between microfinance bank and small-scale business access to capital

Table 9 Correlations

\begin{tabular}{|ll|r|r|}
\hline & & $\begin{array}{c}\text { Microfinance } \\
\text { Bank }\end{array}$ & Small Scale Business \\
\hline Microfinance Bank & Correlation & 1 & .678 \\
& Sig. (2-tailed) & & \\
& $\mathrm{N}$ & 60 & .000 \\
& Pearson & .678 & 60 \\
Correlation & & 1 \\
Small Scale Business & Sig. (2-tailed) & .000 & \\
& $\mathrm{~N}$ & 60 & 60 \\
\hline
\end{tabular}

\section{Source: Authors' Field Survey (2019).}

From table 9, the Pearson correlation (r) analysis between microfinance bank and small-scale business access to capital variables is 0.678 , indicating a strong positive correlation between microfinance bank and small-scale business variables. Thus, the null hypothesis is rejected and it is concluded that there is a significant correlation between microfinance bank and small-scale business access to finance. 


\section{Hypothesis two}

$\mathbf{H}_{2}$ : There is a significant relationship between microfinance banks and small-scale business development

Table 10 Correlations

\begin{tabular}{|c|c|c|c|}
\hline & & Microfinance Bank & $\begin{array}{c}\text { Small Scale } \\
\text { Business } \\
\text { Development }\end{array}$ \\
\hline \multirow{3}{*}{ Microfinance Bank } & $\begin{array}{l}\text { Pearson } \\
\text { Correlation }\end{array}$ & 1 & $.890^{*}$ \\
\hline & Sig. (2-tailed) & & .000 \\
\hline & $\mathrm{N}$ & 60 & 60 \\
\hline \multirow{3}{*}{$\begin{array}{l}\text { Small Scale } \\
\text { Business } \\
\text { Development }\end{array}$} & $\begin{array}{l}\text { Pearson } \\
\text { Correlation }\end{array}$ & $.890^{*}$ & 1 \\
\hline & Sig. (2-tailed) & .000 & \\
\hline & $\mathrm{N}$ & 60 & 60 \\
\hline
\end{tabular}

**. Correlation is significant at the 0.05 level (2-tailed).

\section{Source: Authors' Field Survey (2019).}

From the table 10, the Pearson correlation (r) analysis between microfinance bank and small scale business development variables is 0.890 , indicating a strong positive correlation between microfinance bank and small scale business development variables. Thus, the null hypothesis is rejected and it is concluded that there is a significant relationship between microfinance bank and small scale business development. 


\section{Hypothesis three}

$\mathbf{H}_{3}$ : Microfinance Banks influence rural transformation.

Table 11: Correlations

\begin{tabular}{|c|c|c|c|}
\hline & & $\begin{array}{c}\text { Microfinance } \\
\text { Banks }\end{array}$ & $\begin{array}{c}\text { Rural } \\
\text { Transformation }\end{array}$ \\
\hline \multirow{3}{*}{$\begin{array}{l}\text { Microfinance } \\
\text { Banks }\end{array}$} & $\begin{array}{l}\text { Pearson } \\
\text { Correlation }\end{array}$ & 1 & .809 \\
\hline & Sig. (2-tailed) & & .000 \\
\hline & $\mathrm{N}$ & 60 & 60 \\
\hline \multirow{3}{*}{$\begin{array}{l}\text { Rural } \\
\text { Transformation }\end{array}$} & $\begin{array}{l}\text { Pearson } \\
\text { Correlation }\end{array}$ & .809 & 1 \\
\hline & Sig. (2-tailed) & .000 & \\
\hline & $\mathrm{N}$ & 60 & 60 \\
\hline
\end{tabular}

\section{Source: Authors' Field Survey (2019).}

From table 11, the Pearson correlation ( $r$ ) analysis between microfinance banks and rural transformation variables is 0.809 , indicating a strong positive correlation between microfinance banks and rural transformation variables. Thus, the null hypothesis is rejected and it is concluded that microfinance banks influence rural transformation.

\subsection{DISCUSSION OF FINDINGS}

The major aim of this study was to investigate the effect of microfinance on small scale business development. The result of the study shows that there exists a strong relationship between microfinance bank and small business access to capital. This implies that microfinance banks are the grass roots banks from which the SMEs could obtain loans, the importance of microfinance banks has grown over the years due to this function. Abiola (2012) also has some fact which can be linked up to this result analysis. He finds out that access to loan gives rise to business growth and this can be easily offered by MFI's (Microfinance Institutions). It is also pertinent to note that, due to the rigorous procedures for commercial banks to grant loans, customers have shifted to microfinance banks because they offer lenient procedures in obtaining soft loans; MFIs also give minimal interest rates, and also imbibe the savings culture 
among customers. These overwhelming functions have created a relationship between microfinance banks and access to loans by SMEs.

Further, the study also finds out that there is a relationship between microfinance bank and small-scale business development. This implies that microfinance banks through their basic scheme service encourage small and medium scale business development. Services rendered by microfinance banks ranges from disbursement of loans to advice on management of assets, as well as retirement savings service. The importance of these services by microfinance banks has given rise to business development and growth. This is also in line with Ayozie (1981) who observed that SMEs' operations determine economic growth in terms of internal revenue and creation of employment opportunities. Also, Wang (2013) attests to this by observing that using microfinance brings a significantly higher profit to small and medium scale enterprises.

Finally, the study finds out that microfinance banks influence rural transformation. This implies that microfinance banks through its functions support rural transformation. The idea behind this can be linked up to the disbursement of credit facilities to SMEs, when this is in place, employment sets in, goods and services are in large supply and above all income generation is possible. This feat is expected to yield positive rural transformation as well as increased Gross Domestic Product (GDP) to the nation at large. This result is similar to that of Godson (2013) where he finds out that microfinance has an effect on development of smallscale enterprises as well as a Nation growth at large.

\section{Conclusion and Recommendation}

The study has evaluated the effect of microfinance on the poverty reduction in Nigeria particularly as it affects the small and medium scale enterprises in the study area. The study also confirms that MFIs can serve as catalyst for the growth of SMEs and subsequent development of economy if properly managed.

However, there is need for proper overhauling of microfinance programmes so that the objective of poverty reduction through the disbursement of credit to micro and small enterprises can be achieved. To this end, more strategies and proactive measures are still required to make the dream come true. In addition, more awareness should be created for microfinance programmes by the operators; and the government should create more enabling environment to enable the masses admire MFIs as panacea for poverty reduction and economic development. 


\section{References}

Abiola B. (2012). Effect of microfinance on micro and small enterprises growth. Asian Economic and Financial Review. 2(4), 1-17.

Akpan E.S., Nneji I.D. (2015). Contribution of microfinance banks to the development of small and medium scale enterprises in Nigeria. Research Journal of Finance and Accounting. ;6(8):19-28.

Ali, A.H., Abu-Hadi, A.O. \& Ali, A. Y. S. (2013). The Accessibility of Microfinance for Small Businesses in Mogadishu, Somalia. International Journal of Humanities and Social Science, 3(11), 172-180. $\quad$ Retrieved from http://www.researchgate.net/profile/Ali_Sheikh_Ali/publication/258991083_The_Acces sibility_of_Microfinance_for_Small_Businesses_in_Mogadishu_Somalia/links/547d56b $\underline{60 \mathrm{cf} 285 \mathrm{ad} 5 \mathrm{~b} 088 \mathrm{cac} . \mathrm{pdf}}$

Ashamu, Sikiru O. (2014): The Impact of Microfinance on Small Scale Business in Nigeria. Journal of Policy and Development Studies Vol.9, No 1

Asghar, N. (2012). Microfinancing for Poverty Reduction: An Emperical Study of Rural Areas of Tehsil Gujrat-Pakistan. International Journal of Advances in Management and Economics, 2.1, 34-40.

Ashamu, Sikiru O. (2014): The Impact of Microfinance on Small Scale Business in

Nigeria. Journal of Policy and Development Studies Vol.9, No 1

Ayozie S. N. (1981). Impact of Small Scale Enterprise on a Nation's Economy. European. Journal of Business Management, Vol 2 (6), pp17.

Bashir, M. K., Amin, A., \& Naeem, M. K. (2010). Micro-credit and Poverty Alleviation in Pakistan. Word Applied Sciences Journal, 8(11), 1381-1386.

CBN. (2005). Microfinance Policy, Regulatory and supervisory Framework For Nigeria.Federal Republic of Nigeria.

Copestake, J.G., Duvendack, M., Hooper,L. Loke, Y., Palmer-Jones, R. \& Rao, N. (2010). What is the Evidence of the Impact of Microcredit on the Incomes of Poor People? DFID Systematic Review Protocol,October.

Duku Osei, P. (2002). A critical assessment of Jamaica's national poverty eradication programme. Journal of International Development, 14(6), 773-788. doi:10.1002/jid.923 
Godson A. (2013). The impact of microfinance on the development of small-scale enterprises. European Journal of Business and Management. 5(7), 165-172.

Green, C. J., Kirkpatrick, C. H., \& Murinde, V. (2006). Policy arena finance for small enterprise growth and poverty reduction in developing countries y. Journal of International Development, 18, 1017-1030. doi:10.1002/jid.1334.

Imai, K., \& Azam, M. S. (2010). Does microfinance reduce poverty in Bangladesh? New evidence from household panel data. Journal of Development Studies. Manchester. Retrieved from http://www.tandfonline.com/doi/abs/10.1080/00220388.2012.661853

Kalirajan, K., \& Singh, K. (2009). The pace of poverty reduction across the globe: an exploratory analysis. International Journal of Social Economics, 36(6), 692-705. doi:10.1108/03068290910956921

Martin, I., Hulme, D. \&, Rutherford, S. (2002). Finance for the poor: from microcredit to microfinancial services. Journal of International Development, 14(2), 273-294. doi:10.1002/jid.874

Muller, C., \& Bibi, S. (2010). Refining Targeting against Poverty. Evidence from Tunisia. Oxford Bulletin of Economics and Statistics, 72(3), 381-410. doi:10.1111/j.14680084.2010.00583.x

NAN. (2013, June 24). Nigeria: Microfinance banks invest N222 billion ( $\$ 1.34$ billion) in Nigerian economy - Association. Microfinance Africa. Retrieved from https://www.google.com/?gws_rd=ssl\#q=Microfinance+Africa

Onukwugha, A. (2013, June 18). Nigeria: 76\% of rural dwellers don't patronise banks-NDIC.

Africa.

Retrieved

from https://www.google.com/?gws_rd=ssl\#q=Microfinance+Africa

Onyeagocha, S. U. O., Chidebelu, S.A.N.D., Okorji, E. C., Ukoha, A., Osuji, M. N. \&, Korie, O. (2012). Determinants of Loan Repayment of Microfinance Institutions in Southeast States of Nigeria. International Journal of Social Science and Humanities, 1(1), 4-9.

Roslan, A., \& Abd Karim, M. Z. (2009). Determinants of Microcredit Repayment in Malaysia: The Case of Agrobank. Humanity \& Social Sciences Journal 4(1).

Smith, N. (2010). Economic inequality and poverty: where do we go from here? International Journal of Sociology and Social Policy, 30(3/4), 127-139. doi: $10.1108 / 01443331011033328$

Tang, S. (2002). Determinants of Repayment in Microcredit : Evidence from Programs in the United States *, 26(June), 360-376. 
USAID (2005) "Micro, Small and Medium Enterprises financial services demand survey". Nigeria; USAID Nigeria prism project, USAID publishers.

Wang, X. (2013). The Impact of Microfinance on the Development of Small and Medium Enterprises: The Case of Taizhou, China. The Johns Hopkins University, Baltimore, MD, USA.

Yang, B., Jialali, P., \& Wei, X. (2011). Microfinance in China's Poor Area and Its Impact to Loan Type - Evidence from Xinjiang Uygur Autonomous Region. 2011 Fourth International Conference on Business Intelligence and Financial Engineering, 486-490. doi:10.1109/BIFE.2011.82

Yeboah, E. (2017). The Impact of Microfinance on Grass root Development: Evidence from Smes in Kwabre East District of Ashanti Region of Ghana. Journal of Business and Management 05(04):577-591 DOI: 10.4236/ojbm.2017.54050

https://connectnigeria.com/articles/2015/08/the-nigerian-economy-the-role-of-smes.....See 